\title{
The extinction of the Ukrainian culture of the Polish-Ukrainian-Slovak borderland and the image of the "Ukrainian Banderite" in Polish and Czechoslovak literature, journalism and cinematography, mid-1940s-1980s
}

\author{
Roman Drozd, Michal Šmigel’
}

\author{
Prof. dr hab. Roman Drozd \\ Pomeranian University in Słupsk \\ Institute of History \\ Arciszewskiego 22a, \\ 76-200 Słupsk \\ Poland \\ e-mail: roman.drozd@apsl.edu.pl \\ Assoc. Prof. Michal Šmigel', Ph.D \\ University of Matej Bel in Banská Bystrica \\ Faculty of Arts \\ Department of History \\ Tajovského 40, \\ 97401 Banská Bystrica \\ Slovakia \\ e-mail: michal.smigel@umb.sk
}

Muzeológia a kulturne dedićstvo, 2020, 8:2:91-116

DOI: $10.46284 / \mathrm{mkd} .2020 .8 .2 .6$

The extinction of the Ukrainian culture of the Polish-Ukrainian-Slovak borderland and the image of the "Ukerainian Banderite" in Polish and Crechoslovak literature, journalism, and cinematography, mid-1940s1980s

The aim of this study is to outline the process of the extinction of Ukrainian culture in south-eastern Poland as a result of Polish resettlement actions and the activities of the Ukrainian underground movement (i.e., the Ukrainian Insurgent Army) in the post-war period (1944-1947). Concurrently, the study offers an analysis of the image of the "Ukrainian Banderite", created by propaganda in Polish and Czechoslovak literature, journalism, and cinematography in the period from the mid-1940s to the end of the 1980s. The authors state that both in Poland and in Czechoslovakia the analysed topic has been subject to certain cyclical waves of interest, or current political demand or usefulness, but always according to an established and politically accepted template. The black-and-white reception of the issue, propaganda fictions, the concealment of facts, and the disproportionate highlighting of others, which were applied in the literary and film production of the real-socialist period, only distorted the historical objectivity of the issue and created a complicated stereotype in the collective memory.

Keywords: Ukrainians in Poland, Polish-Soviet resettlements, Operation Vistula, Ukrainian Insurgent Army, image of "Banderite", propaganda, literary and film production of the real-socialist period, stereotypes of the collective memory

\section{Introduction}

Only a few kilometres from the Slovak border on the territory of adjacent Poland (northeast of the Dukla Pass, or east of Barwinek) is the unique open-air Museum of the Lemko Culture in Zyndranowa. Yet in the far and wide surroundings there is no longer the continuous Lemko (Ukrainian) settlement which once existed here. This extinct unique culture is now 
R. Drozd, M. Šmigel': The extinction of the Ukrainian culture of the Polish-Ukrainian-Slovak borderland...

only commemorated by annual cultural festivals (such as a Lemko bonfire among others). The Lemkos (an ethnographic sub-group of the Ukrainians in Poland) were to share the fate of the broader Ukrainian minority in Poland-deportation. Taking place in the first years after World War II as a result of Polish-Ukrainian antagonism and the desire to establish an ethnically homogeneous Polish state without national minorities, in the case of the Lemkos specifically this displacement was from their home region of Lemkivshchyna in south-eastern Poland to the territory of Ukraine and northern and western Poland.

The founding of a Lemko museum was initiated in 1968 by Teodor (Fedor) Gocz, who was a manager of the museum until his death in $2018 .{ }^{1}$ His aim was to preserve the culture of the Lemkos that had lived in these places until 1947. Gocz's fate was to reflect that of Ukrainians in Poland. Although his family avoided resettlement to Soviet Ukraine and deportation during Operation Vistula, as the resettlement operation was called, Teodor himself (when he was 18 years old) was arrested in June 1947 and accused of "sympathising" with the Ukrainian Insurgent Army (UPA [we use this original abbreviation in this paper], or the so-called Banderites), tortured, and finally sentenced to prison. He was released in 1951 and only in 1954 did he return to Zyndranowa to the house of his great-grandfather, Teodor Kukiel (who due to his being 80 years old had not been deported). Subsequently, he began activities related to the resurrection of the Ukrainian culture in the region. For this activity he was again arrested and sentenced to three years in prison in 1958. After his second return from prison, however, he again became engaged in the promotion of the Ukrainian culture and folklore, and subsequently he founded the Memorial Room of Lemko Culture in a house of his great-grandfather. This act started his museum-making activity and also the long process leading to the establishment of the museum. He collected objects related to the history and culture of the Lemkos, as well as monuments from the battle in the Dukla Pass in 1944. With his own resources he built a memorial to the participants in this battle, but for the Ukrainian title and militant character of the work he again came into confrontation with the communist government in Poland. The memorial was blown up in 1976 and Teodor Gocz faced persecution once again. ${ }^{2}$ In 1999 he published a memoir, Life of Lemko, describing his life. ${ }^{3}$ Undoubtedly, his fate and the history of his open-air Museum of the Lemko Culture in Zyndranowa could form the object of a special study (even on the Slovak version of Wikipedia there is an absence of articles on him and his museum).

This present study, however, aims to demonstrate a wider scope of the issue than the outlined fate of that one important Lemko cultural actor. The attentive reader will not have missed the fact that Gocz was persecuted in communist Poland for his belonging to the Ukrainian ethnic group and for his activities reviving the Ukrainian culture. This study's aims, however, are: to outline the process of the extinction of the Ukrainian culture in the Polish-Ukrainian-Slovak borderland (in south-eastern Poland) as a result of displacement actions and the operation of the Ukrainian Insurgent Army (UPA) in the post-war period (1944-1947); and to analyse the propaganda image of the "Ukrainian Banderite", first in Polish literature, journalism, and cinematography, and subsequently in the Czechoslovak ones (from the mid-1940s to the late 1980s), because the issue of the resettlement of Ukrainians and the activities of the Banderites

\footnotetext{
${ }^{1}$ On the Ukrainian museums see SHNITZER, Igor. Museum Affairs at the Territory of Subcarpathian Rus' in the Years of the First Czechoslovak Republic (1919-1938). In: Muzeologia a kulturne dedičstvo, vol. 7, 2019, is. 1, pp. 99-110.

${ }^{2} 40$ rokiv Mezeju lemkivskoji kultury v Zyndranovij. L'viv 2009, pp. 3-12.

${ }^{3}$ GOCZ, Teodor. Życie Łemka. Zyndranowa 1999.
} 
also resonated in Czechoslovak literary and film production (a part of Polish literature also being "imported"). In other words, we shall try to point out a very interesting phenomenon whereby the components of the material cultural heritage of the majority society (and nondemocratic regime), together with the use of propaganda tools, create an image of an enemy minority culture and thus contribute to creating a complicated stereotype in the collective memory.

\section{Discussion and results}

In 1944, the communists in Poland were faced not only with the problem of taking over and strengthening their power, based on the support of the Soviet Union, but also with the question of the future Polish-Soviet border. It was obvious that the outcome of this issue would depend on the will of the Soviet leader Joseph Stalin, who fully controlled the Polish communists. When they thought about power, and that was their main goal, they agreed on far-reaching concessions to the Soviet state, including on the question of Poland's eastern border, which in principle had "shifted" Poland to the west. On 26-27 July 1944 the Polish National Liberation Committee (PVNO), as the representative of the communist government in Poland, agreed in secret with the Soviet government to redesign the Polish-Soviet border. It was agreed to set the borderline along the so-called Curzon Line with small deviations in favour of Poland. Obviously, it was at that time that the idea of resettling Poles from the USSR, and of displacing the Belarusians, Lithuanians, and Ukrainians from Poland, was born. In September 1944, the PVNO signed resettlement agreements with the partially Soviet Union republics: Belarus, Lithuania, and Ukraine (the so-called "Lublin Agreements"). There is no doubt that the person who had initiated these agreements was Stalin, who cared about creating an ethnographic border between Poland and the USSR. He probably wanted to put before the Western Allies the final result and to gain their approval for the new course of the border. With the change of borders, Poland also adopted the idea of an ethnically homogeneous state (due to what they considered their negative experiences with minorities during the interwar and war periods), and purged the two largest minorities. On the newly acquired western (formerly German) territories began the resettlement of Germans (about 7 million) and on the eastern parts, that of Ukrainians (about 700,000). At the same time almost 800,000 Poles were resettled from the USSR (i.e. from the territory of the former eastern Poland).

The resettlement of Ukrainian nationals from Poland to the USSR, specifically to the Soviet Ukraine, began on 15 October 1944. At the beginning (in the so-called voluntary phase), families which had lost property or relatives due to the transition of the front and the PolishUkrainian conflict were resettled. Also many of those who were worried about their future life in Poland were moving east. On the other hand, poor people were attracted by Soviet propaganda presenting non-existant welfare in a new place of settlement. It is estimated that by December 1944 only about 20,000 people had resettled. ${ }^{4}$ However, most Ukrainians were not interested in resettlement and wanted to stay in their homeland. Despite some governmental measures at the end of 1944, the voluntary resettlement almost came to a halt, and some Ukrainians even began to flee back to Poland. The cruel truth about the drastic situation in the USSR - news of post-war hunger, collective farms, injustice, and problems with the local population of Ukraine-also came to the people.

${ }^{4}$ PISULIŃSKI, Jan. Przesiedlenia Ukraińców do ZSRR w latach 1944-1946. In: Biuletyn Instytutu Pamieci Narodowej, 2001 , nr 8, p. 38. 
R. Drozd, M. Šmigel': The extinction of the Ukrainian culture of the Polish-Ukrainian-Slovak borderland...

In early 1945, the Polish government proceeded to begin coercive actions, which due to the approaching deadline for resettlement hardened (initially, it was to have been implemented by February 1945, and then the deadline for resettlement was postponed). In the first half of 1945, people living in the area of south-eastern Poland were frightened of the looting of Ukrainian villages, realised by criminal groups and armed sections of the Polish underground movement. Last but not least, there were murders and a terrorisation of the population (it is estimated that in the first months of 1945, between 2,600 and 3,900 Ukrainians were murdered in 75 municipalities). ${ }^{5}$ Nor had the many petitions and requests asking for protection and addressed to government authorities helped. In some cases, the population even recognised masked Polish security officials-militiamen and soldiers_-among the members of criminal groups. ${ }^{6}$ The Ukrainian population, in turn, used all means to avoid resettlement-by changing nationality and proclaiming loyalty to Poland, creating militia, escaping into border forests, or crossing the Czechoslovak borderline. ${ }^{7}$ This position did not change until the end of the resettlement. Resistance by the Ukrainians caused the government to start their forced displacement from Poland, which was also in line with the mood of a part of Polish society and some representatives of local authorities in this area. ${ }^{8}$ By September 1945, over 220,000 Ukrainians had been resettled. ${ }^{?}$

On 3 September 1945, the 3rd, 8th, and 9th Infantry Divisions of the Polish Army were sent to south-eastern Poland to displace Ukrainians (the so-called forced phase of resettlement). Security authorities also recommended the resettlement of mixed families, unless the father was a Pole. ${ }^{10}$ The army relocated entire villages and gave the villagers only two hours to prepare for departure. Resettlement actions were often accompanied by violence and cruelty from the army. "At the time of these operations", says Polish historian G. Motyka, "the army fired at everyone who ran. And they ran ... just everyone! Soldiers looted possessions, beat the population, in some places raped women, and burnt dwellings." 11 Such behaviour certainly did not apply to all soldiers and their commanders. For example, while the chief of staff of the 5th Military District, Brigadier General Adam Daszkiewicz, recommended that "the army should treat all Ukrainian men as bandits, should take them away, and even shoot some of them", ${ }^{12}$ on the other hand, the commander of the 5th Military District Division, General Mikołaj Więckowski, urged officers to "put an end immediately to all atrocities and the abuse of the innocent civilian population of the Rzeszów Voivodeship". ${ }^{13}$ In practice, the behaviour of the troops depended on the attitude of the commander conducting the action, as well as on the individual attitudes of ordinary soldiers. ${ }^{14}$

\footnotetext{
${ }^{5}$ MOTYKA, Grzegorz. Tak byto w Bieszrzadach. Walki polsko-ukrajińskie 1943-1948. Warszawa 1999, pp. $239-241$.

${ }^{6}$ HALCZAK, Bohdan. Łemkowszczyzna w latach 1944-1947. In: Pivdenyi arxiv (istorychni nauky). Vyp. XVI. Cherson 2004, p. 278.

${ }^{7}$ On the issue of Ukrainians fleeing to the territory of Czechoslovakia, see: ŠMIGEL', Michal. K otázke lemkovských utečencov (z Pol'ska) na Slovensku v rokoch 1945-1946. In: Forum historiae, 2009, vol. 3, is. 1, pp. $133-149$.

${ }^{8}$ Archiwum Ministerstwa Spraw Wewnętrznych i Administracji (AMSWiA), f. Polski Komitet Wyzwolenia Narodowego (PKWN), sygn. 6.

${ }^{9}$ PISULIŃSKI, J. Przesiedlenia Ukraińców do ZSRR..., p. 39.

${ }^{10}$ AMSWiA, f. Ministerstwo Administracji Publicznej (MAP), sygn. 134.

${ }^{11}$ MOTYKA, Grzegorz. Tak byto w Bieszczadach..., s. 285.

12 Repatriacja czy deportacja. Przesiedlenie Ukraincón z. Polski do USRR 1944-1946. T. 2. Dokumenty 1946. Pod red. E. Misiły. Warszawa 1999, dok. 40, pp. 93-95.

${ }^{13}$ Op. cit., dok. 146, p. 289.

${ }^{14}$ Op. cit., dok. 168, pp. 333-334.
} 
Unfortunately, the pressure and coercion, which caused injustices to the civilian population, had one more negative effect. A Ukrainian underground arose to defend the displaced population. As early as 1945, the Ukrainian Insurgent Army's military staff moved part of their forces from western Ukraine to south-eastern Poland. The ranks of the UPA were also strengthened by men from the local Ukrainian population, who decided to defend their fatherland with rifles in their hands. In this way, the UPA forces increased considerably. While in the spring of 1945 there were 4-5 sotnias of the UPA in Poland (a sotnia = about 100 insurgents), in May 1946 their number increased to $16-17$ sotnias. ${ }^{15}$ The displacement of the Ukrainian population meant a real problem for the UPA: the loss of a civilian presence and communication channels with the West was putting its further activity in this area under question. Therefore, the UPA command adopted measures to protect the civilian population against the invasion of the army and Polish robber groups, or to prevent the displacement of people. Eventually, these measures allowed its activity even after the removal of a significant part of the population.

The UPA units paralysed communication routes, blew up bridges and railways, set traps, and attacked Polish military and security forces. They attacked resettlement offices and transport stations ${ }^{16}$ and carried out propaganda and agitation activities. ${ }^{17}$ In October 1945, an open letter "To the whole civilised world" was drafted and translated into several languages, informing the international community of the tragic situation of the Ukrainians in Poland. ${ }^{18}$ These steps caused a large part of the Ukrainian population to start perceiving the UPA warriors as defenders of their lives and property. On the contrary, Poles perceived them as bandits and criminals. Unfortunately, the actions of the Ukrainian underground led to the brutalisation of the Polish force structures and the region of south-eastern Poland found itself in a terrible situation. The Ukrainian civilian population was in the midst of a struggle between the UPA and the Polish army. However, due to a clear prevalence of the Polish military force, the activities of the Ukrainian underground and the resistance of some of the population could not prevent the displacement; at most they could only delay it.

Nearly 479,000 people were resettled into the USSR between 15 October 1944 and the end of June $1946 .{ }^{19}$ Despite the official termination of the process of resettlement, individuals and families could still resettle, because the final term was the end of 1946. About 10,000 people took advantage of this opportunity. ${ }^{20}$ As a result, between 1944 and 1946, a total of 489,000 Ukrainians from Poland were largely forcibly resettled into Soviet Ukraine. ${ }^{21}$ However, this was not the end of the idea of the clearing of south-eastern Poland of its Ukrainian population. In the region were still about 200,000 Ukrainians.

\footnotetext{
${ }^{15}$ MOTYKA, Grzegorz. Od Wołynia do akcji “Wisła”. In: Więz, 1998, nr. 3, pp. 123-126.

${ }^{16}$ AMSWiA, f. Ukraińska Powstańcza Armia (UPA), sygn. X/40.

${ }^{17}$ See: DROZD, Roman. Ukrainska Powstańcza Armia. Dokumenty - struktury. Warszawa 1998, pp. 158-206; WYSOCKI, Jasek. Ukraincy na Lubelsz̧çyźnie w latach 1944-1989. Lublin 2011, pp. 62-74.

${ }_{18}$ AMSWiA, f. Organizacja Ukraińskich Nacjonalistów (OUN), sygn. IX/4.

${ }^{19}$ Deportacji. Zachidni zemli Ukrajiny kincia 30-ch - poczatku 50-ch rr. Dokumenty, materialy, spohady. T. 2. 1946-1947 rr. Lwiw 1998, dok. 43, p. 173. See also: Centralne Archiwum Wojskowe (CAW), f. Sztab Generalny WP, sygn. IV.111.480; CEPENDA, Ihor. Ukrajinśko-polski widnosyny 40-50-ch rokiw XX stolittia: etnopolitycznyj analiz. Kyjiw 2009, pp. 119-203.

${ }^{20}$ Deportacji..., T. 2, dok. 43, p. 173; SZCZEŚNIAK, Antoni B., SZOTA, Wiesław Z. Droga do nikeqd. Džiałalność Organizacji Ukrainskich nacjonalistów i jej likwidacja w Polsce. Warszawa 1973, p. 231.

${ }^{21}$ For further details concerning the fate of Ukrainians from Poland resettled to Soviet Ukraine, see: KABACZIJ, Roman. Wygnani na stepy. Przesiedlenia ludności ukrainskiej z Polski na południe Ukrainy w latach 1944-1946. Warszawa 2012.
} 
R. Drozd, M. Šmigel': The extinction of the Ukrainian culture of the Polish-Ukrainian-Slovak borderland...

In February 1947, further displacement of the Ukrainian population began, this time to the western and northern regions of Poland, from where the original German population had been displaced. Its realisation was planned for the autumn of 1947 -immediately after the harvest of Ukrainian farmers. ${ }^{22}$ However, on 28 March 1947 near the village of Jabłonka in the Bieszczady Mountains, in unexplained circumstances, Karol Świerczewski, the assistant minister of national defence, was assassinated. The government immediately attributed this crime to the Ukrainian underground, although it had no evidence. His death was so mysterious that even special commissions established for this purpose could not identify the perpetrators. ${ }^{23}$ Finally, this event was to become an ideal excuse for the process of deportation.

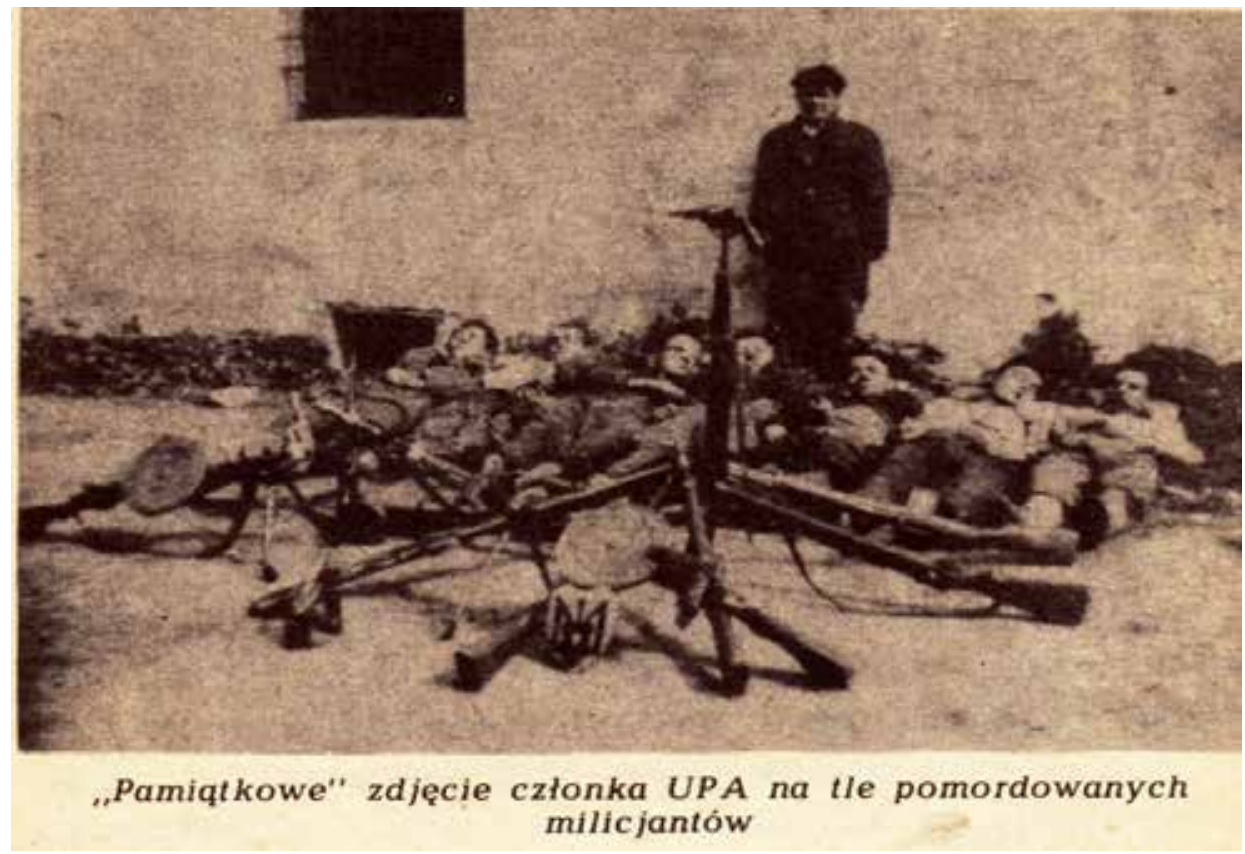

Pict. 1: Propaganda photograph.

Source: BATA, Artur: Biesz̨rzady w ogniu. Rzeszów 1987, p. 142.

From that moment on, preparations for the deportation action were sped up. Polish society also began to be convinced of the exceptional personality of Świerczewski. On the one hand, the legend of "a general who did not bow to the bullets" began to spread, and on the other hand, obloquy of the Ukrainians started. In a commentary published in Życie Warszany the death of Świerczewski was commented upon in this way:

"He fell at the hands of Ukrainian fascists. We know these hands. They are the hands of the "SS Galizien Division". Even those of the Brigade of Kaminski. The same ones that murdered 200,000 Poles in Volhynia. The same ones which murdered the women and children of the Warsaw Uprising. The ones which burnt and destroyed the defenceless capital of Poland. The ones which ruthlessly awakened the exiles of Wola and Starówka at night and were looking for sacrifices for her bestiality". ${ }^{24}$

\footnotetext{
${ }^{22}$ See: DROZD, Roman. Polityka wtadz wobec ludności ukrainskiej w Polsce w latach 1944-1989. Warszawa 2001, pp. 66-68.

${ }^{23}$ For more details, see: HALCZAK, Bohdan. Tajemnica śmierci generała Karola Świerczewskiego. In: $W$ kregu polityki. Eds. A. Ilciów, R. Potocki, R. Kessler. Zielona Góra 2010, pp. 140-148.

${ }^{24}$ Życie Warszawy, 29. 03. 1947.
} 
The commentary contained false information. The Ukrainians were denoted as fascists, and accused of participating in the suppression of the Warsaw Uprising, of the murders of Warsaw citizens, and for the excessive number of Polish victims in Volhynia. The Ukrainian character was also quickly bestowed upon the purely Russian Kaminski Brigade. Unfortunately, this propaganda was so effective that similar statements can still be found today. There was a strong call for revenge for the death of Świerczewski. J. Wasilewski, for example, appealed thus on the pages of Driennik Ludowy: "The remnants of Ukrainian fascist groups have remained. They must be removed in the most radical way. The death of General Swierczewski must be avenged as soon as possible!"25

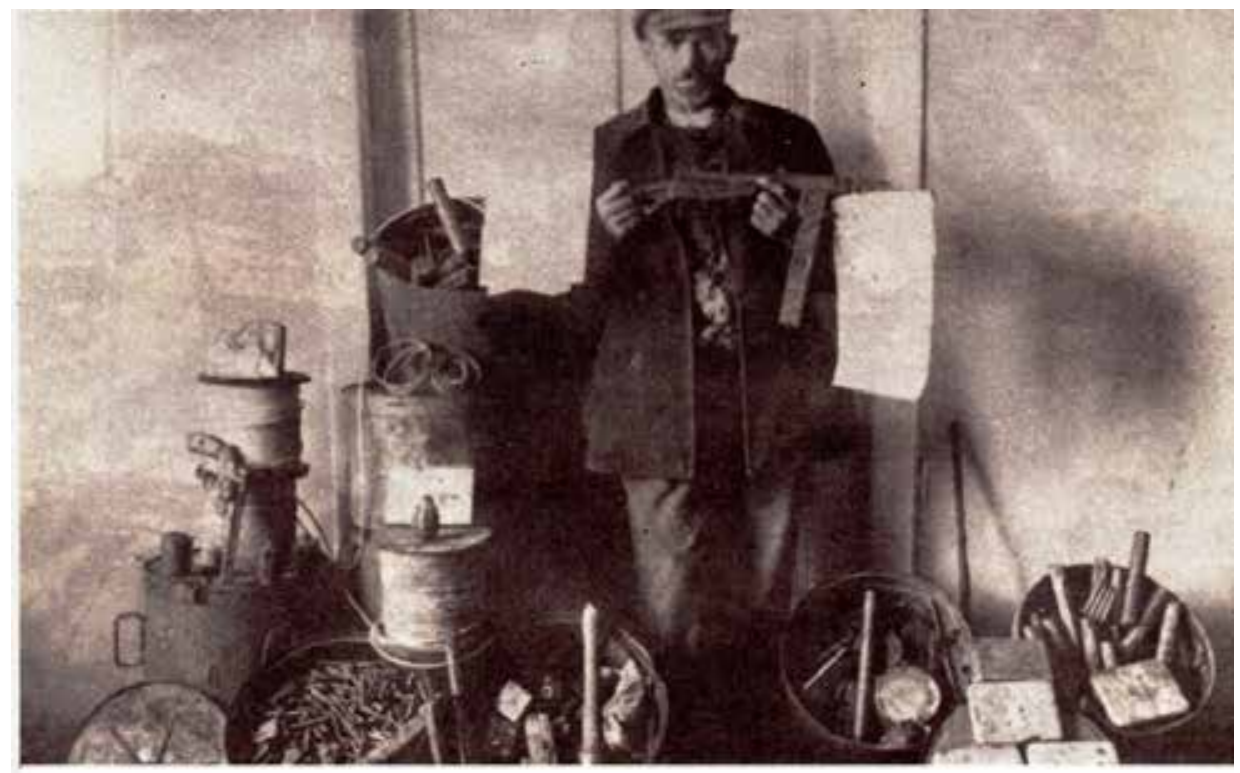

\section{Jeden z sympatyków UPA ze swoim arsenałem}

Pict. 2: Propaganda photograph.

Source: Siedem rozmów ₹ generatem dywizji Wtadystawem Pożoga I zasteppa ministra spraw wewnetrznych, szefem wywiadu i kontrwywiadu. Rozmawiał H. Pecuch, Warszawa 1987, p. 189.

"Correctly-directed" films began to be made, and special-purpose photographs were taken that "featured" the captured members of the Ukrainian underground movement or their supporters (see photos nr. 1-2). In particular, the murders of Poles committed by the UPA warriors were promoted "out loud". The government encouraged the organisation of numerous gatherings in towns and villages, at workplaces, offices, and schools, which called for the establishment of order and the "extermination of the bands". ${ }^{26}$

In fact, the Ukrainian underground movement did not pose a real threat to Poland and its communist authorities. As a result of the fighting with the Polish Army and Soviet NKVD

\footnotetext{
${ }^{25}$ Dziennik Ludowy, 31. 03. 1947; KMITA, Małgorzata. Propaganda antyukraińska i kształtowanie negatywnego stereotypu Ukraińca w czasach PRL. In: Problemy Ukrainców w Polsce po wysiedleńczej akcji "Wisła” 1947 roku. Pod red. W. Mokrego. Kraków 1997, p. 60.

${ }^{26} \mathrm{LACH}$, Stanisław. Osadnictwo ludności ukraińskiej na ziemiach odzyskanych po II wojnie światowej. In: Akcja "Wista" na tle stosunków polsko-ukraińskich w XX w. Pod red. J. Farysia i J. Jekiela. Szczecin 1994, p. 158.
} 
R. Drozd, M. Šmigel': The extinction of the Ukrainian culture of the Polish-Ukrainian-Slovak borderland...

troops in 1947 the UPA had only 1,500 soldiers $^{27}$ and about 500 armed members of the civilian militia. ${ }^{28}$ The Polish army command was aware of this. In February 1947 the commander of the 8th Division operating in Bieszczady wrote to the Minister of National Defence, M. Zymierski: “

There is a relative peace in the area. On roads and railways, which in the first half of 1946 could not be used without special military protection, transit is taking place normally today, without fear of possible bandit attacks. The area is under the control of the military and security authorities, and the groups of bandits that sporadically appear in the south and southeast border zone are still being tracked and destroyed by our troops". ${ }^{29}$

The death of Świerczewski undoubtedly accelerated the intention to displace the Ukrainian population from its residential area near the Slovak and Ukrainian borders. Primarily it was aimed at the Ukrainian minority and only secondly at the UPA. At the meeting of the Politburo of the Central Committee of the Polish Workers' Party on 29 March 1947, when a political decision was taken to deport the Ukrainians, repressive measures against the Ukrainian population were clearly spoken of, not the fight against the UPA. The Ukrainian underground movement was not mentioned at all. ${ }^{30}$ The discussion centred around an initial deportation plan called Operation East. Only during the discussion was it decided to emphasise that the aim of the deportation action was not only to displace the population but also to destroy the UPA. The course of Operation Vistula (Polish: "Akcja Wisła") also clearly indicates that it was concentrated mainly on the displacement of the population. The number of troops to be deployed in the operation was estimated on the basis of the number of villages from which Ukrainians were to be displaced, not on the number of the existing UPA units. ${ }^{31}$

On 24 April 1947, the Presidium of the Council of Ministers of Poland approved a resolution concerning Operation Vistula. Four days later, the Vistula Operation Group, specially created for this purpose, began to deport Ukrainians to areas of western and northern Poland. ${ }^{32}$ From a military point of view, this action went smoothly. At dawn, the army surrounded the villages and ordered the inhabitants to prepare for the journey, giving them only two hours to pack and take the necessary things with them. Then the people were escorted by the army to collection camps, where people from several villages were being gathered together. From there they marched to loading stations, where the deported were divided into groups (mixed such that members of a group were not from one village) and transported by train under the supervision of the army to various places in western and northern Poland. For the future rapid assimilation envisaged in the plans, people were resettled in different parts. It is estimated that more than 140,000 people were deported in Operation Vistula (April-July 1947). Resettlement continued in the following months. Overall, 150,000 Ukrainians were deported to the northwest of Poland, including almost 4,000 people dismissed from the Jaworzno concentration

\footnotetext{
${ }^{27}$ MISIŁO, Eugeniusz. Ukrajinci u Polszczi (1944-1947). Heneza akcji „Wisła”. In: Ukrajina i Polszcza miż, mynulym i majbutnim. Upr. A. Pawlyszyn. Lwiw 1991, p. 13.

${ }^{28}$ MOTYKA, Grzegorz. Ukrainska partyzantka 1942-1960. Działaność Organizacji Ukrainskich Nacjonalistów i Ukraińskiej Powstańczej Armii. Warszawa 2006, p. 588.

29 Akecja „Wista”. Dokumenty. Opr. E. Misiło. Warszawa 1993, p. 22 (wstęp).

${ }^{30}$ Archiwum Akt Nowych (AAN), f. Komitet Centralny Polskiej Partii Robotniczej (KC PPR), sygn. $295 /$ V-3.

${ }^{31}$ Akcja „Wista”. Dokumenty. Opr. E. Misiło. 2. wyd. Warszawa 2012; Polska i Ukraina w latach traydziestych - czterdziestych XX wieku. T. 5. Akcja „Wista” 1947. Warszawa-Kijów 2006; SNYDER, Timothy. Rozwiązać ostatecznie problem ukraiński w Polsce, 1943-1947. In: Nowa Ukraina, 2007, nr 1-2, pp. 15-41; OLCHAWA, Maciej. Akcja „Wisła”: motywacje czystki etnicznej. In: Nowa Ukraina, 2007, nr 1-2, pp. 43-49.

${ }^{32}$ See: PISULIŃSKI, Jan. Akecja specjalna „Wisła”. Rzeszów 2017.
} 
camp (officially: Central Labour Camp).

Operation Vistula was also accompanied by army brutality. Certainly, violence was not a permanent part of the deportations; the brutality rate rather depended on the attitude of the commander and soldiers who participated in the action. Nevertheless, the propaganda spread among them encouraged the use of violence. In the prepared materials entitled "Hitler's Heirs" and "Fighting the Bands is our Soldier's Duty", the UPA members and Ukrainian "assistants" were described as robbers, fascists, and murderers of the Polish population. According to them, Banderites were used by the Germans for particularly bloody pacifications and they were famous for their brutality in suppressing the Warsaw Uprising. ${ }^{33}$ The "Field Guide to the Soldier" warned that "the bandit is generally not different from the ordinary person the soldier will meet". ${ }^{34}$ The above statements were intended to consolidate the image of the "Ukrainian Bandit" in the minds of the soldiers. This aim was also supported by the image of a Ukrainian, disfigured by the propaganda, who was portrayed as an "armed, dirty, and unshaven individual" in contemporary photographs and films (see photos nr. 1-3).

In a leaflet entitled "Against the Deceived Members of the UPA", rebel commanders were called "servants of bloody Hitler, former SS-men and police", and in the leaflet "To the local People", the blame for displacement was put on the UPA and the population itself: "Ukrainian villages became natural nests of bands, sowing fear and violence". ${ }^{35}$ As Krystyna Kersten rightly points out, the deportation of the Ukrainian population from south-eastern Poland “

has resulted in hardly quantifiable material losses - the depopulation and devastation of the Bieszczady region, and huge moral damage. The specific culture of the Polish-Ukrainian border was practically destroyed. The brutal methods of mass forced displacement, intended to solve the "Ukrainian problem" in Poland, had a negative impact on the consciousness not only of the deported Ukrainians, but also of the Poles. After all, it did not solve the "problem", it only further complicated the already complicated relationships". ${ }^{36}$

The displacement of the Ukrainian population and systematic counter-insurgency actions greatly weakened the UPA and, as a result, it dissolved in Poland. Weakened sotnias from the kuren (battalions) Bajdy and Rena left for Soviet Ukraine or they tried to escape (through Czechoslovakia) to the West as early as June 1947. Similarly, in August 1947 sections of the Zalizniak battalion left Poland. In September the Berkuta battalion was dissolved. Some of the dissolved insurgents and their families were displaced to the north-western regions of Poland. In south-eastern Poland, only a small group of guerrilla warriors remained to secure illegal channels of communication between the West and insurgents in Ukraine. ${ }^{37}$ The heads of command of the Ukrainian underground movement in Poland were also annihilated. In October 1947, OUN's regional head, Jaroslav Starukh, shot himself in a bunker that was surrounded by men of the Internal Security Corps, and the UPA commander in Poland, Miroslav Onyshkevych, was arrested in March 1948 in Lower Silesia and subsequently sentenced to death. According to the findings of the Polish Institute of National Memory over the duration of Operation Vistula about 1,000 Ukrainians were shot dead. ${ }^{38}$

\footnotetext{
${ }^{33}$ CAW, f. Główny Zarząd Polityczno-Wychowawczy WP, sygn. IV.112.290.

${ }^{34}$ Op. cit.

${ }^{35}$ AAN, f. Ministerstwo Administracji Publicznej (MAP), sygn. 781.

${ }^{36}$ KERSTEN, Krystyna. Narodziny systemu władzy. Polska 1943-1948. Poznań 1990, p. 341.

${ }^{37}$ MOTYKA, G. Ukrainska partyzantka..., p. 587.

${ }^{38}$ DZIUROK, Adam, GAŁEZZOWSKI, Marek, KAMIŃSKI, Lukasz, MUSIAŁ, Filip. Od niepodległości do niepodległości. Historia Polski 1918-1989. Warszawa, 2010, p. 238.
} 
R. Drozd, M. Šmigel': The extinction of the Ukrainian culture of the Polish-Ukrainian-Slovak borderland...

Of course, the government could not reveal the main purpose of Operation Vistula, as it contradicted communist slogans about democracy, friendship between nations, and the brotherhood of the working people. Therefore, it was justified in terms of the extermination of the UPA, thus transferring responsibility for its implementation to the Ukrainians themselves. It was a planned way to hide the crime committed. ${ }^{39}$ In this way, communist propaganda was to work throughout the entire existence of the Polish People's Republic (1944/52-1989).

The generation and subsequent maintenance of the negative image of the Ukrainian in Poland, which was associated with the epithets "Ukrainian nationalist", "Banderite", and "murderer", was of variable intensity and individual waves of more intense occurrence are observable. Concerning the shifts in this image, there is also an apparent dependence on the internal political situations in Poland. In particular, the anti-Ukrainian campaign intensified during the political crisis of the regime, when the Ukrainian minority demanded their rights.

During Operation Vistula, the activity in this area was concentrated in the publishing of newspaper articles, the taking of photographs, and the production of short propaganda films, as well as the calling of meetings in workplaces, etc. All these activities were supposed to stimulate the feeling of the threat of the Ukrainian underground and the cooperating Ukrainian population. The message was unambiguous and it pointed to the need for the deportation of Ukrainians (although they were Polish citizens). Another wave took place after 1956, when, after the establishment of the Ukrainian Socio-Cultural Association (Polish: Ukraińskie Towarzystwo Społeczno-Kulturalne) and under the influence of the political "thaw" in Poland caused by the events of the "Polish October", the Ukrainian community demanded the condemnation of Operation Vistula and their return to their original places of settlement. Anti-Ukrainian machinations were re-launched, repeating the tendentious image of Ukrainians from the post-war years. This time, pro-regime works of literature were involved along with articles in the press. Fiction with a certain "purpose" emerged, which in a sensational and emotional way (and at the same time falsely) depicted the fight against the UPA. Among the most popular novels falsifying the image of the Polish-Ukrainian conflict in south-eastern Poland were The Glow in Bieszczady (Polish: Luny $w$ Bieszczadach) by Jan Gerhard, ${ }^{40}$ which became a bestseller in 1960, and Traces of Lynxes Claws, written by Wanda Żółkiewska. ${ }^{41}$ Both novels were also compulsory school reading (the first in secondary schools and the second in primary schools) and they were to form a negative image of Ukrainians among new generations of Poles. Another anti-Ukrainian wave came after the political crisis in Poland in the years 1968-1970. It was marked by a continuation of activities from the previous period, but supplemented with a new element. In 1973 the book written by General Apolinary Oliwa When Blessings to the Knives were Given (Polish: Gdy posiniecano noże) appeared. ${ }^{42}$ The book was written in the form of memories and the killing of the Poles by the UPA units in Volhynia was described on its pages several times. Although the events described did not concern the Ukrainians deported from Poland, they gave birth to a myth of a ritual blessing of the knives in Ukrainian churches before the act of killing. By this myth the memory of the bloody Polish-Ukrainian conflict in Volhynia was strengthened, as well as the negative image of the "Ukrainian-killer". Finally, the last wave came in the 1980s-another period of crisis for the regime, associated with the emergence of the Solidarity (Solidarność) movement.

\footnotetext{
${ }^{39}$ The Polish Institute of National Memory recognizes the Operation Vistula as a crime of communism. On the other hand, M. Olchawa proves that it was an ethnic cleansing. OLCHAWA, M. Akecja „Wista”..., pp. 43-49.

${ }^{40}$ GERHARD, Jan. Luny w Bieszczadach. Warszawa, 1959.

${ }^{41}$ ŻÓEKIEWSKA, Wanda. Ślady rysich pazurów. Warszawa.1965.

${ }^{42}$ OLIWA, Apolinary. Gdy poświęcano noże. Opole. 1973.
} 


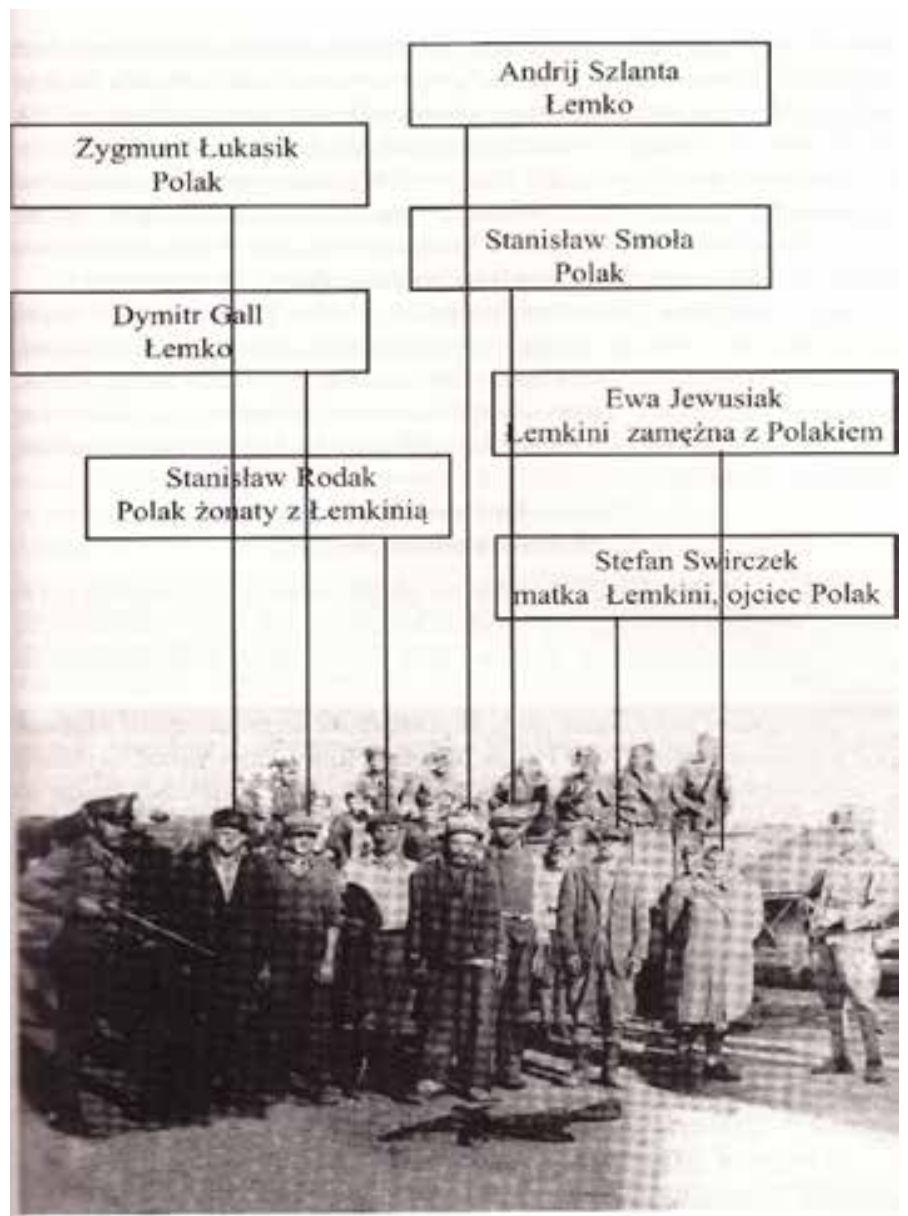

Pict. 3: Propaganda photograph ostensibly depicting members of the UPA in capture. In fact, the people in the picture were the inhabitants of the village of Losie, close to Gorlice, of Ukrainian and Polish nationality, who were later identified.

Source: WOLOSIUK, Leszek: Historia jednej fotografii ze wsi Łosie. In: Problemy Ukrainców w Polsce po wysiedleńczej akcji „Wisła” 1947 roku. Pod red. W. Mokrego. Kraków 1997.
Typical of this period were the books by Edward Prus and Artur Bata, which appeared in the late 1980 s, i.e., in the last stage of socialist Poland. A total of 58 scholarly and non-fiction works, 50 memoirs, 10 volumes of the popular series Yellow Tiger, ${ }^{43}$ and more than 60 novels were published in Poland on the post-war Polish-Ukrainian conflict.

In literature, the "inconvenient" facts were omitted and those "necessary and exposed", their significance often exaggerated, were particularly emphasised. Authors also falsified the facts and wove unreal events, adapting them to the desired communist rhetoric (see photo nr. 4-5). Example can be picked out from Gerhard's aforementioned book: for instance, there is the scene of a "dance at the minefield", which is a total fake, or the scene of the decapitation of captured Polish soldiers using a carpenter's axe. ${ }^{44}$ Michal Fijałka, in his work on the 27th Volhynia Infantry Division of Armija Krajowa (1986), wrote: "The most tragic was the murder 'ceremony' itself, usually associated with the blessing of a priest and the blessing of murder tools-axes, scythes, rakes, crowbars, and weapons." 45 At the same time, the facts regarding killings of the Ukrainian population committed by Polish soldiers, militia, and security officials or members of the Polish underground movement were concealed and ignored. This issue has been similarly presented in a number of articles, non-fiction books, and scholarly papers, as well as in radio broadcasts and television programmes.

\footnotetext{
${ }^{43}$ The Library of Yellow Tiger (Polish: Biblioteka Żółtego Tygrysa)—a book edition of historical character, published by the Ministry of National Defense of Poland in the years 1957-1989. It consisted of small-format volumes focused on episodes of World War II. A total of 420 books were published in this series.

${ }^{44}$ For more details on this topic, see: MOTYKA, Grzegorz. W kregu „Łun w Bieszczadach”. Szkice z najnowszej bistorii polskich Bieszczad. Warszawa, 2009; TRUCHAN, Myroslaw. Nehatywnyj stereotyp ukrajincia w polskij pislawojennij literaturi. Mjunchen-Lwiw. 1992.

${ }^{45}$ FIJAŁKA, Michał. 27. Wotyńska Dywizja Piechoty AK. Warszawa, 1986, p. 46.
} 
R. Drozd, M. Šmigel': The extinction of the Ukrainian culture of the Polish-Ukrainian-Slovak borderland...

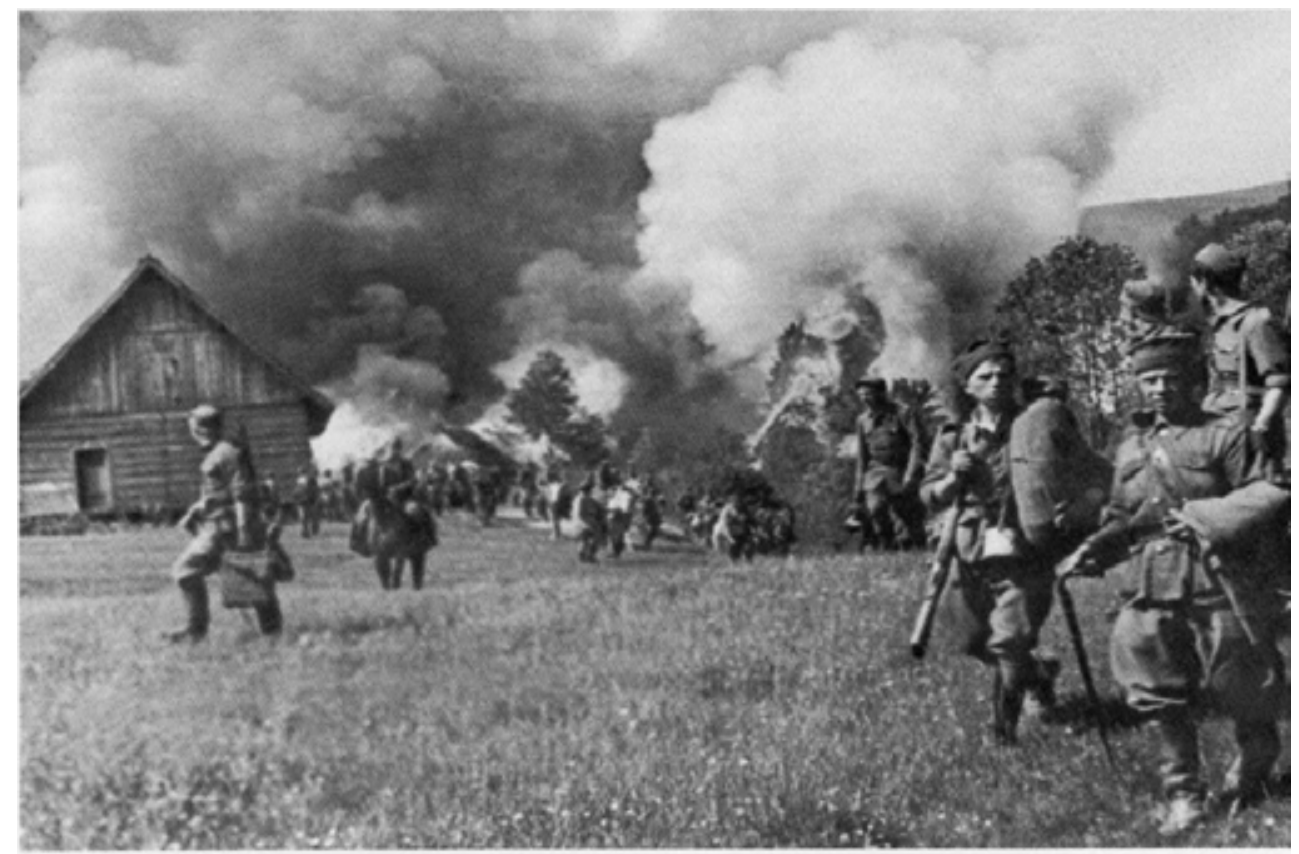

Rzeszowszczyzna, 1947. Pacyfikacja wsi podezas Akcji „Wisła”.

Fot. Jan Gerhand, archiwum Jerzego Tomaszewskiego

Pict. 4: Ukrainian village burnt by the Polish army; original photo published in the magazine Karta (nr. 49/2006, p. 39).

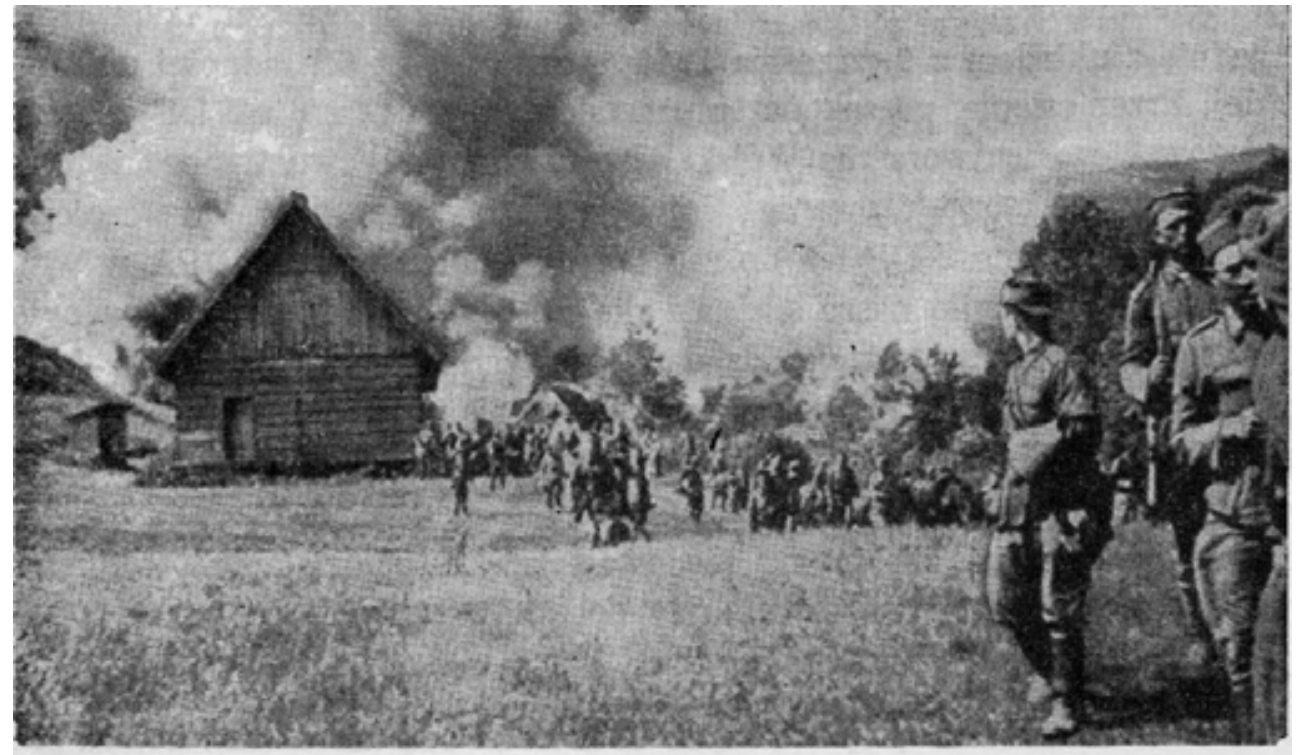

\section{Wieś podpalona przez banderowców}

Pict. 5: Photograph of the retouched original with statement that the village was burnt by the Banderites. Source: SZCZEŚNIAK, A.B., SZOTA, W. Z.: Droga do nikad..., p. 362. 
Assessing the content, only a few works were scientific, but they were intended for a small circle of experts. Examples of this are Ryszard Torzecki's work The Ukrainian Question in Politics of the Third Reich 1933-1945 (1972), ${ }^{46}$ or Andrzej Kwilecki's book Lemkos: The Issue of Migration and Assimilation (1974), ${ }^{47}$ which for years previously could not have appeared due to the State Security objections. The monograph by Antoni B. Szcześniak and Wiesław Z. Szota The Road to Nowhere: Activities of the Organisation of Ukrainian Nationalists and its Destruction in Poland, published in 1973, ${ }^{48}$ could also be included in this group of books. The last one was very quickly withdrawn from bookshops and libraries and a portion of the impression has been destroyed, as some of the facts were in contradiction with the then-spread propaganda image of the UPA.

At least three feature films have been made on the subject. The most popular of these was The Sergeant Kaleń (Polish: Ogniomistrz. Kaleñ), a film adaptation of Gerhard's novel Luny $w$ Bieszrzadach. The film did not differ significantly from the literary text and continued to spread negative anti-Ukrainian stereotypes. It was made in 1961 and was directed by Ewa and Czesław Patelski (a pro-regime director, who in 1959 had introduced himself with the film Base of the Dead People on the topic of fighting with the UPA). Other films followed: in 1963, The Broken Bridge (director Jerzy Passendorfer) and in 1968 Wolf Echoes (director Alexander ŚciborRylski). These films were screened-several times and deliberately_at the time of Ukrainian (i.e. Orthodox and Greek-Catholic) Christmas. ${ }^{49}$

Such a negative image was also created by many memorial sites, including memorials and plaques dedicated to victims of fighting with the UPA, including the most important memorial to General K. Świerczewski, in Jabłonka. Originally, a smaller obelisk was installed in 1957, which was replaced in 1962 by a massive monument - a granite obelisk crowned with a stylised Piast eagle, designed by Franciszek Strynkiewicz. Until 1989, the memorial was the destination of the marches of young "pioneers" (members of the children's organisation) on the "last road of General Walter Świerczewski”. (The memorial was disassembled in 2019 and its fragments moved to the exposition of Soviet propaganda memorials at the Polish Institute of National Memory.) In addition to the memorial, a museum dedicated to the "heroic death of the general" and to the fights with the Banderites was established in Jabłonka. The museum (which ceased to exist in 1990) was a mandatory stop for all school trips to the Bieszczady Mountains. Exhibitions in the rooms of military memorabilia of the units that had fought against the UPA also played an important role in this respect. Their purpose was to "appropriately" affect the mind of the soldiers of the Polish People's Army.

On the other hand, traces of the centuries-old existence of Ukrainian culture in the region of south-eastern Poland (from where many Ukrainians were deported) were removed. An example of this was the fate of Greek-Catholic and Orthodox churches ("cerkvi"). Before World War II, 552 churches were in the jurisdiction of the Roman Catholic Diocese of Przemyśl, of which only 269 shrines "had survived". Most of them—which "did not survive"-were deliberately

\footnotetext{
${ }^{46}$ TORZECKI, Ryszard. Kwestia ukrainska w polityce III Rzeszy 1933-1945. Warszawa, 1972.

${ }^{47}$ KWILECKI, Andrzej. Łemkowie. Zagadnienie migracji i asymilacji. Warszawa, 1974.

${ }^{48}$ SZCZEŚNIAK, Anton B., SZOTA, Wiesław Z. Droga do nikąd. Driałalność Organizacji Ukraińskich Nacjonalistów i jej likwidacja w Polsce. Warszawa, 1973.

${ }^{49}$ OLSZAŃSKI, Andrzej Tadeusz: Na drodze do pojednania. In: Res Publica, 1988, nr 11, p. 64.
} 
R. Drozd, M. Šmigel': The extinction of the Ukrainian culture of the Polish-Ukrainian-Slovak borderland...

destroyed.$^{50}$ In the socialist Poland there was no state museum ${ }^{51}$ which would present Ukrainian culture, nor any exhibition of it. In the existing open-air Museum of Folk Architecture in Sanok, with its vast collection of wooden churches, residential and utility buildings, ceramics, and folk instruments, the objects were not presented as monuments of the Ukrainian culture, but only as artifacts of regional groups of Lemkos and Boykos. The fact that these are Ukrainian ethnic groups was cautiously concealed. Similarly, the expositions of icons were presented only as "Orthodox" or "Greek-Catholic", and as Carpathian, i.e. without affiliation to nationality.

The propaganda images of the Ukrainian nationalist who was portrayed as a "bandit and murderer", and of the entire Ukrainian underground movement as fascist and collaborating with the Germans, maintained and deepened a sense of antipathy and even hostility towards the Ukrainians in Polish society. ${ }^{52}$ The whole community of the Ukrainian minority in Poland was accused of cooperating with the UPA (i.e., the principle of collective guilt was applied). Ukrainians thus became viewed as staunch nationalists and enemies of Poland and the Poles. The guardian of this attitude became not only the regular censors, but also the communist secret services, who tried to eliminate opinions that were not in accordance with official statements. Certainly, it would be very simplistic to blame the post-war propaganda for the mutual aversion of Poles and Ukrainians. The hostility was born in the previous decades and its origin probably dates back to the period of the Polish-Lithuanian Union (so-called First Rzeczpospolita). Subsequently, it sharpened in the interwar period and culminated during the Second World War. ${ }^{53}$ The communists did not cause this aversion, but they supported and sustained it by propaganda. Of course, this in no way justifies those propaganda efforts; formally, the communists had declared repeatedly that the power they obtained would be used for the sake of the state and for the benefit of the nation, and that it must strive for the harmonious coexistence of citizens and not divide them. ${ }^{54}$

$$
* * * * *
$$

As for the view of the displacement of the Ukrainian population from Poland and the image of the "Ukrainian Banderite" in the period of real-socialist Czechoslovakia, in principle it did not differ from the Polish, but there are some differences. However, in the case of the Ukrainian minority which inhabited the north-eastern part of Slovakia, the Czechoslovak post-war government (like the Polish one, seeking to homogenise the state without national minorities) did not choose such drastic ways to reduce the minority, although the inspiration of the Lublin Protocols is proven. The government used them as a template in concluding two agreements on the mutual resettlement of the population from the USSR (1945-1946), but the

\footnotetext{
${ }^{50}$ BRYKOWSKI, Ryszard. W sprawie architektury cerkiewnej województwa rzeszowskiego po 33 latach. In: Losy cerkwi w Polsce po 1944 roku. Rzeszów, 1997, pp. 151, 155.

${ }^{51}$ NIEROBA, Elżbieta. National Museums and Museums of Modern Art in Poland: Competition for Domination in the Field of Museums. In: Muzeologia a kulturrne dedičstvo, vol. 6, 2018, is. 2, pp. 45-58.

${ }^{52}$ For more details, see: MOTYKA, Gregorz. W kregu „Lun w Bieszczadach”. Szkice z najnowszej bistorii polskich Bieszczad. Warszawa, 2009; MĘDRZECKI, Włodzimierz. Obraz Ukraińca w polskim dialogu publicznym po drugiej wojnie światowej. In: Wotyń i Chotmsžczyna 1939-1947 rr. Polśko-ukrajinśke protystojannja ta joho widtunnja. Doslodżennja, dokumenty, spohady. Lwiw, 2003, pp. 353-367.

53 SZELAŻYK-KOMENDA, Ołena. Temat Ukrainy w literaturze polskiej. Paradoks mitu Ukrainy. In: Biuletyn Ukrainoznawczy, nr 12. Przemyśl, 2006, pp. 111-123; LOZOWSKA, Katarzyna Renata: Wokół stereotypu Ukraińca. In: Polska-Ukraina: historia, polityka, kultura. Pod red. S. Zabrowarnego. Szczecin-Warszawa, 2003, pp. 11-26.

${ }^{54}$ For details see: DROZD, Roman. Ukraincy wobec swojej przeszłości (1947-2005). Warszawa, 2013.
} 
principle of voluntary resettlement was indeed fulfilled by the Czechoslovak side. ${ }^{55}$ Even in the frame of the activities of the UPA units in Czechoslovakia in the post-war years 1945-1947, ${ }^{56}$ the Ukrainian minority as such was not blamed as supporting or cooperating with them (and indeed, actually did not do so). As for the support of the Banderites, Czechoslovak communists blamed, rather, domestic political opponents-non-communist parties, especially the Slovak Democratic Party, as well as the Greek-Catholic Church. The aim in this was to discredit them during the struggle to establish the communist regime in Czechoslovakia in 1947-1948. ${ }^{57}$

It was this perspective that was transferred into contemporary propaganda, to scholarly and artistic writings in Czechoslovakia. For instance, a comment piece entitled "Benderovci" by an anonymous author, which was published at the beginning of 1947 in the newspaper Východoslovenská pravda, states thus: “

Unknown men with machine guns in their hands. What kind of people are they? In their stomachs, gypsies forge nails [i.e. they are hungry], they do not have food ration tickets, but they have "long fingers" [i.e. they are thieves]... What else do they have? Great prospects for the future: the rope, the hook, and the beams of the gallows, or the "heroic" death behind the hump with the tongue out. In Poland, their soles are burnt on the hot soil..."

An almost "prophetic" impression was given by Michal Mareš, published in August 1947at the time of the crossing of the territory of Czechoslovakia of two UPA sotnias (Hromenka and Burlaki) with the aim to enter the American Zone in Germany: “

They are herds of military, political, and criminal offenders ... They go from east to west, and individuals or groups can emerge anywhere. Once they have crossed our western frontiers, they are safe; they will certainly not return. But for now the Banderites are among us. And we shall hear a lot about them. Real and fantastic". 59

And looking back, in view of the historical evidence, it is necessary to agree with the last two sentences of the author.

It should be noted that even in Czechoslovakia the issue of the UPA has been the subject of certain conjunctural waves of interest, or has at particular times served certain political needs or usefulness ${ }^{60}$ (but always according to the established and politically accepted template, as was the case in Poland). Czechoslovak historiography "successfully" avoided it, or studied it very sporadically and marginally. As a result, the scope for political journalism and similarly focused non-fiction literature has expanded. They basically substituted for professional historical literature until the end of the 1980s. Due to the absence of serious and impartial academic research throughout this period, the individual findings were only repeated periodically. As

\footnotetext{
${ }^{55}$ In 1947, 12,000 Ukrainians resettled voluntarily in the territory of Soviet Ukraine-about 13\% of the then minority. See: ŠMIGEL', Michal, KRUŠKO, Štefan. Opcia a presidlenie Rusinov do ZSSR (1945-1947). Bratislava, 2011.

${ }^{56}$ See: ŠMIGEL, Michal. Banderovci na Slovensku (1945-1947). Banska Bystrica, 2007.

${ }^{57}$ ŠMIGEL', Michal, SYRNÝ, Marek. „Rázne a prísne proti banderovcom...“ Bezpečnostné a politicko-spoločenské aspekty prienikov oddielov Ukrajinskej povstaleckej armády na územie Československa v rokoch 1945-1947. In: Acta bistorica Neosoliensia, 2019, vol. 22, is. 2, pp. 37-45; RĚPA, Tomáš. Ukrajinští nacionalisté a komunistická propaganda. Zneužití tématu v Československu po roce 1945. In: Pamět’ a dějiny, 2014, vol. VIII, is. 2, pp. 47-57.

${ }^{58}$ Benderovci. In: Východoslovenská pravda, 4. 01. 1947.

${ }^{59}$ MAREŠ, Michal. Banderovci se blíží... In: Dnešek, 7. 08. 1947, p. 295.

${ }^{60}$ As A. Hruboň stated, the Slovak "legal definition does not reflect the scientific dialogue [...] and what is worse, orders the historians as well as the broader public (sometimes under the threat of sanctions) how to define the historical terms, how to interpret historical events and personalities". HRUBOŇ, Anton. K identifikácii protikomunistického odboja na Slovensku (o interpretačnom labyrinte jeho historickej, právnej a spoločenskej roviny). In: Historický časopis, 2015, vol. 63, is. 3, p. 504.
} 
R. Drozd, M. Šmigel': The extinction of the Ukrainian culture of the Polish-Ukrainian-Slovak borderland...

a result, propagandistic fiction, distorted facts, and inexistent events have formed a sort of unchallenged myth and stereotype of the "Antibanderite Legend".

The first book publication on the matter, which, however, did not deviate from journalism by its nature and which resembles a pamphlet, was the brochure entitled "Real Face of Banderites: Operation B Against the Civil Network", written by Václav Slavík and published in 1949 (Slovak translation published in 1950). ${ }^{61}$ It was an extended version of a series of articles published by the author in the communist weekly magazine Tvorba in 1948. Slavík's text is characterised by the typical vocabulary and stylisation of the then communist press. The author strongly attacked those who had allegedly been a threat to Czechoslovak, Polish, and Soviet statehood. Accused persons were primarily Greek Catholic priests (indeed, the Vatican itself) and the Slovak Democratic Party. The author emphasised the link between the Ukrainian liberation movement and the interests of Nazi Germany. He even attributed the creation of the UPA to the strategic plans of the "German Secret Staff". Yet Slavík did not knowingly distinguish the specification of the individual groups of the Ukrainian political spectrum-he labelled all of them Banderites, including members of the 14th Division SS "Galizien". The author often contradicts himself while describing the situation in Slovakia. Mentioning the public's opposition and rejection of the "Banderite assassins", he also referred to the "rather substantial support of the civilian population". He also mentioned the different approach of Banderites to Slovaks and Czechs, allegedly because Slovaks are "soaked in the spirit of the People's Party". Undoubtedly, Slavík's brochure represents a propaganda pamphlet. It cannot be evaluated as a significant source of historical knowledge on the UPA issue in post-war Czechoslovakia; rather it could be considered to contribute to our knowledge of the political practice of the Czechoslovak Communist Party. This short text (39 pages) contributed to the formation of the basic contours of the "Antibanderite Legend", which the Czechoslovak communists were able to use propagandistically to discredit their political opponents.

After some period of silence, the UPA issue appeared again in the late 1950s-early 1960s in non-fiction and fiction literature. In 1965, the book In the Sign of the Trident, written by František Kaucký and Ladislav Vandůrek, appeared on the Czechoslovak book market. ${ }^{62}$ It was evidently created in cooperation with the StB (State Security) and with the approval of the communist party structures (the first of the authors was a collaborator of the Ministry of Interior and the second an employee of it). The book consisted of short, fictionalised reports (with a predominance of dialogues) devoted to individual episodes in the fight against Ukrainian nationalists (in the authors' perception, criminals) and their domestic assistants and sympathisers. In this sense, the most remarkable is the chapter entitled "Bus Perforated by Bullets", ${ }^{63}$ which interestingly corresponds to the chapter from the book of memories of the high Polish security officer Stanisław Wałach "There Was a Time in Poland"64 (in Slovak translation published under the title Action Against Bandits at the beginning of the 1970s). In Slovakia, the same reports written by Kaucký and Vandurek were published in 1965 in Predvoj, the weekly of the Central Committee of the KSS for politics, culture, and economy.

Fiction also had a special place in the literature on the UPA. Under the conditions of the totalitarian state, it fulfilled an important ideological function and also shaped the historical awareness of the public in a "desirable" direction. It allowed the various thematic elements

\footnotetext{
${ }^{61}$ SLAVÍK, Václav. Pravá tvár banderovcư: Akece B proti civilni siti. Praha, 1949.

${ }^{62}$ KAUCKÝ, František, VANDŮREK, Ladislav. Ve znameni trojzubce. Praha, 1965.

${ }^{63}$ KAUCKÝ, F., VANDŮREK, L. V znameni trojzubca, pp. 144-149.

${ }^{64}$ WAŁACH, Stanisław. Byt v Polsce czas... Kraków, 1969.
} 
of propaganda to be presented in an accessible way through compelling stories. The interest of the security forces in the aforementioned fiction was also documented in conclusions, often written by State Security (ŠtB) officers. In the 1950s and 1960s, several translations of Polish novels and short stories were published in Czechoslovakia. First, in 1951, the Slovak translation of a book for young readers entitled On a Man who Did Not Dodge the Bullets by Janina Broniewska was published (the Czech translation of the book under the title Generál Karel Świerczewski, bohatýr polskébo osvobození being published in 1953). In 1958, a collection of short stories Fight by Wacław Biliński was presented. ${ }^{65}$ Of course, the main topic was the struggle against the Banderites in the Polish-Ukrainian borderlands. And in 1962 a novel followed by the aforementioned author J. Gerhard, published under the title Fires in the Carpathians (the Polish original title being Łuny w Bieszczadach). ${ }^{66}$

It should be noted, however, that J. Gerhard as an officer of the Polish army had had his own combat experience in south-eastern Poland and in the book he has tried to capture dramatic events in the form of reports. Undoubtedly, the author was an "important actor in the events" - in the rank of colonel he had commanded one of the most brutal units of the Polish army, one which had terrorised and brutally intervened against the civilian Ukrainian population in Poland during its displacement to the Soviet Union (1944-1946). The so-called Polish Battalion of Death of Captain Michalski, which became "famous" for its brutality in the pacification of Ukrainian villages, was part of Colonel Gerhard's brigade.

More fiction books on Banderite themes were published at the beginning of the 1970s in the so-called "period of normalisation". The protagonists of party ideology and cultural policy perceived the topic of the UPA as a suitable model for fostering the idea of an ideological struggle with external and internal enemies. In addition, with a sufficient time distance, it was a "substitute" theme during the so-called "age of immobility". Translations from Polish and Russian literature, as well as original novels by Slovak and Czech authors, were published. Undoubtedly, translations from Polish had a prominent place among them.

Another translated novel was Władysław Jarnicki's The Burnt Land (in the Polish original, Spalona ziemia) ${ }^{67}$ It captures not only approximately three years of the civil war in Poland, but the author also paid attention to combat actions against the UPA in Czechoslovakia. This was followed by the publication of the non-fiction genre (reportage series) In the Shadow of the Trident by Stanisław Myśliński (in Polish, Strzały pod Cisna : Bieszczady 1946; for the Czech edition the text was extended by the author). ${ }^{68}$ It presents events from south-eastern Poland in the period 1944-1948 from the perspective of the Polish party and state circles (describing looting, destruction, and acts of terrorism committed by the UPA units, while highlighting the combat heroism of members of the Polish army and security forces). The author did not reflect at all the tragedy of the displaced Ukrainian minority in Poland, the brutality of the Polish government forces, etc. Finally, in 1980, the Slovak translation of the aforementioned novel Traces of Lynxes Claws $^{69}$ by Wanda Żołkiewska was also published. ${ }^{70}$

\footnotetext{
${ }^{65}$ BILINSKIJ, Wacław. Boj. Praha. 1958.

${ }^{66}$ GERHARD, Jan. Požáry v Karpatech. Praha. 1962.

${ }^{67}$ JARNICKI, Władysław. Spálená země. Praha. 1972.

${ }^{68}$ MYŚLIŃSKI, Stanisław. Ve stínu trojzubce. Praha, 1973.

${ }^{69}$ ŻOLKIEWSKA, Wanda. Stopy rysích pazúrov. Košice 1980.

${ }^{70}$ See: VESELÝ, Luboš. „Proti fašistickým bandám UPA“. Ukrajinci v propagandě lidového Polska. Soudobé dějiny, 2010, vol. 17 , is. 4 , pp. 679-688.
} 
R. Drozd, M. Šmigel': The extinction of the Ukrainian culture of the Polish-Ukrainian-Slovak borderland...

In 1972, the original novel by the Slovak author Ladislav Beňo Dangerous Zone appeared, ${ }^{71}$ with a focus on the period 1945-1948 and the environment of the Slovak mountains as a scene of combat clashes with the Banderites. Characterising the basic features of the UPA members, the author stated that they were compromised people (former SS officers) "who were afraid to put down their weapons and return home because they were guilty and had betrayed their own nation during the war, had committed various crimes, and now had become allies of fascist organisations and opponents of the popular democratic regime". ${ }^{72}$ Beňo quite effectively and impressively combined real facts with fiction and self-interpretation. ${ }^{73}$

The topic of the UPA also found its place in original Czech fiction. In 1978, Jaroslav Netolička's novel Time of Foggy Nights was published. ${ }^{74}$ As was the case with J. Gerhard and L. Beňo, J. Netolička too was a direct participant in the campaign against the UPA (in the autumn of 1947), which was reflected to some extent in certain parts of his book. It has a thoughtful ideological construction. Although the cover of the book bears a statement about a basis in true events, the story itself is an obvious fiction. The image of the "Ukrainian Banderite" is depicted by the author in extremely negative terms: especially, an inability to feel any mutual solidarity, not to mention a coldness in their relationships with other people. According to the author's literary license, the behaviour of and motivation for the actions of the Banderites and their "home helpers" lay only in greed and pathologically murderous tendencies.

The most noteworthy book published on the topic of the UPA before the fall of the communist regime in Czechoslovakia was the non-fiction publication The Banderites (Banderovci) by Bohuš Chňoupek (a journalist, politician, and diplomat in the time of Husák's normalisation period). ${ }^{75}$ The author has obviously studied a large amount of archival material, memoirs, and scholarly literature of Czech, Slovak, Polish, and Ukrainian origin. Working on the book, Chňoupek was undeniably approaching the topic with a pre-formed belief in the "obviously monstrous form of Ukrainian bourgeois nationalism". Despite the "advancedness of the time" of the 1980s, he was unable to approach this issue objectively, he did not even try to empathise with the Ukrainians, and his condemnation of them is very clear. Therefore, he also used traditional terminology with expressive words for anything related to the UPA ("bands", "bandits", "Huns", "invaders of Genghis Khan", "Banderite lairs", etc.), as well as some wellknown ideas formulated and taken from Slavík. Chňoupek did not avoid inaccuracies, errors, and contradictions in his extensive novel; he also used unverified and unverifiable pieces of information. On the other hand, the author introduced some themes not previously discussed in the literature (e.g. attempts to establish an independent Ukrainian state, Ukrainian emigration in interwar Czechoslovakia, the high representation of intelligence in the OUN and UPA, the tragic resettlement of Ukrainians in Poland, the depopulation of the Bieszczady Mountains, etc.). The book by Chňoupek has met with great interest and is published periodically in the Czech Republic to this day.

In addition to original fiction (including several popular texts within literary subsystems), television and film productions have also been intended for the public. Their importance in the creation of the "Antibanderite Legend" must be particularly emphasised, especially in

\footnotetext{
${ }^{71}$ BEŇA, Ladislav. Nebezpeŕná zóna. Bratislava, 1972.

${ }^{72}$ Op. cit., p. $90-91$.

${ }^{73}$ See: KMEŤ, Miroslav. Vecná a umelecká literatúra o problematike Ukrajinskej povstaleckej armády v Československu pred rokom 1990. In: Acta historica Neosoliensia, 2005, vol. 8, pp. 168-169.

${ }^{74}$ NETOLIČKA, Jaroslav. Cas mlhavých nocí. Ostrava, 1978.

${ }^{75}$ CHŇOUPEK, Bohuš. Banderovi. Bratislava, 1989.
} 
consideration of the high opinion-forming function of television media in the process of reaching out to the general public, especially in the 1950s and 1970s. In Czechoslovakia the Banderites issue was presented in the film Operation B (Akece B, 1951), directed by Josef Mach, and based on the text of Eduard Fiker. It was very successful among viewers in the 1950s and was screened in other countries of the Soviet bloc. In 1952, Mach was awarded the state prize of II degree. The critic A. Novak, aka Jan Žalman, slightly criticised the film: "This film was aiming for a great goal. However, it got stuck halfway..."76 Other members of the period's press, however, wrote generally positively about the film. The film itself depicted the events of 1947 associated with the crossing of the UPA unit Burlaka through the territory of Slovakia and the struggles of the Czechoslovak army and security forces with the "band". However, in later years the film was withdrawn from the film screen, apparently because of excessive ideologisation, untrustworthy political manipulation, and "artistically creative" distortions of actual events. The historical fidelity was mainly distorted in the hyperbolisation of the brutality of the Banderites in scenes, for example, of the burning of villages in Poland, or of wild assaults of Slovak villages (with pictures of bandits shooting Slovak peasants, brave communists, old women, costumed girls, etc.). The film shows also the supporters of the UPA among the priests of the Greek-Catholic Church and the leaders of the Democratic Party, who are linked to the Western espionage network. The film is the cinematographic equivalent of Slavík's pamphlet.

One of the episodes of the popular TV series Thirty Cases of Major Zeman (Tricetprípadi majora Zemana), entitled "Ruby Cross" ("Rubínový křrižz", 1976), focused more or less on revealing the civilian network of Ukrainian nationalists and its connection with Western intelligence services. ${ }^{77}$ The TV series is regularly screened in the Czech Republic and Slovakia till today. Shadows of a Hot Summer (Stiny horkého léta, 1977) by František Vláčil was another very successful action film, repeatedly screened on Czechoslovak television, usually on the Day of the National Security Corps (17 April). These films were typical products of the era; they create the image of "Banderite fascist bloodthirsty groups" which was suggested to Czechoslovak viewers. ${ }^{78}$

The monograph of Jan Fiala Report on Operation B (Zpráva o Akci B) has become the imaginary peak of historical research results in the former Czechoslovakia (at the same time completing the research of the history of the UPA in the author's professional career). ${ }^{79}$ Fiala focused on the course of Czechoslovak actions against the penetrating groups of the UPA and their crossing through the territory of Czechoslovakia in the years 1945-1947. The book is based on the outcomes from extensive archival research on Czech and Slovak archival materials. In the chapters describing the history of the Ukrainian liberation movement, or evaluating and assessing the activities of the UPA, the author has remained in line with interpretations common for the period prior to year 1989. He unambiguously described UPA members as fascists, or as the "remains of fascism", even though he refused the traditional labelling of the UPA units as "bands" or "gangs" because, as the author put it, they were essentially a "militarily organised and guided force".

In the introduction to his work, he criticises the non-fiction and fiction literature published in Czechoslovakia. Despite the proclaimed effort to clarify the previously distorted interpretations

\footnotetext{
${ }_{76}$ ŽALMAN, Jan. Akce B. In: Kino, 1952, č. 7, pp. 164-165, 167.

77 See: BLAŽEK, Petr, CAJTHAML, Petr, RƯŽIČKA, Daniel. Kolorovaný obraz komunistické minulosti. Vznik, natáčení a uvedení Třiceti případů majora Zemana. In: Film a dějiny. Praha 2005, p. 293.

${ }^{78}$ See: ŘEPA, Tomáš. Banderovci. Politické souvislosti, následky zneužití tématu komunistickou propagandou, návaznost na bybridni konfliket v soućasnosti. Praha 2019, pp. 297-303.

${ }^{79}$ FIALA, Jan. Zpráva o akeci B. Praha 1994.
} 
of events, the author has not always succeeded. Although he was aware of the repression by the Polish post-war government of the Ukrainian population during a forced resettlement (the author speaks of the joint contribution of the Polish authorities and the anti-communist opposition to violence against Ukrainians in Poland) ${ }^{80}$ he did not sufficiently accept the government's share in the incitement of the UPA's activities in Southeast Poland.

Fiction (both original and translated) on the subject of the UPA was of a different quality in Czechoslovakia. It was perceived as a branch of popular literature, as it was allowed to use mainly elements of thrill, drama, and adventure. The blending of artistic narrative and precise facts was in most cases unbalanced, "artificial" from an aesthetic point of view, and characterised by a distinctive black and white evaluation. In the case of both factual and artistic literature it is clear that they were-in regard to the political sensitivity of the topic-under the patronage of the security forces of the regime and thus complied with the intentions of propaganda. The elaboration of this politically usable topic was necessarily subject to the careful scrutiny of the state's political and power structures.

It should therefore be noted that the publisher of this literature in Czechoslovakia was mainly the Ministry of the Interior and Defence, specifically the National Security Corps (ZNB). In particular, the National Security Corps "adopted" and "appropriated" the topic (at the expense of the army - as J. Fiala pointed out in his articles). The campaign against the Banderites (1945-1947) became a deliberate building of the pillars of the Corps' fighting traditions in a struggle with the outside class enemy and a domestic "reaction". This was reflected in a number of publications dealing with the establishment and development of the ZNB (from the 1960s to 1970s), as well as in the exhibitions of the Border Guard Museum in Prague (since 1973 the Museum of the National Security Corps and Units of the Ministry of the Interior), or in numerous exhibition rooms of martial traditions and fame. In addition to the $\mathrm{ZNB}$, the Association of Slovak Partisans was often involved in the commemorating of the "anniversary of the fighting with the Banderites" in Slovakia.

On the other hand, in the "civil" museum sphere of Slovakia, or of Czechoslovakia, the topic of Banderites was not covered. In particular, the issue of "fascist Banderites-Ukrainian nationalists" was considered inappropriate and counterproductive in the framework of the state policy of the Ukrainianisation of the Ruthenian minority in Slovakia (from the beginning of the 1950s; see below). Soldiers and civilians who had died in the time of the fighting with the Banderites also found themselves on the periphery of interest. Only the names of six aspiring soldiers (who died in a combat clash with UPA warriors in August 1947 on the hill of Lupčianska Magura, south of Partizánska Lupča) were carved on the side of the Slovak National Uprising memorials in Ružomberok and Partizánska Lupča. Also, the graves of two communists, killed by alleged Polish Banderites at the end of 1945 in Nová Sedlica (district of Snina), were declared a National Cultural Monument. But the Jews from the neighbouring villages of Ulič and Kolbasov, who were brutally murdered (four in the village of Ulič and eleven in the village of Kolbasov), were not deemed to deserve such special respect. A memorial plaque to the Jewish victims of the massacre in Kolbasov was unveiled only in $1996 .{ }^{81}$

\footnotetext{
${ }^{80}$ Op. cit., p. 39.

${ }^{81}$ ŠMIGEL, Michal. Neobjasnené vraždy Židov v Sninskom okrese na konci roku 1945. Tragédia v Kolbasove a jej pozadie. In: MARCINEKOVÁ, J. et al. Fragmenty židovstva (Snina a okolie). Snina 2018, pp. 61-85.
} 


\section{Conclusion}

The images of the UPA as "Ukrainian Banderite" as created in the communist propaganda of Poland and Czechoslovakia (and even earlier in the Soviet Union) were almost identical, and their propaganda mechanisms worked on the same principle. From the Soviet model they took over the linking of the UPA with fascism, and later with Western espionage. It was in this manner that both the Czechoslovak and Polish communist propaganda accused their political opponents of supporting "Ukrainian fascism". Propaganda makers in both countries employed the proven tactic of evoking a threat and uncovering a conspiracy against the "legitimate" government of the working people. In connection to conspiracy they were looking for internal and external enemies. At the same time, they glorified and heroicised the deployment of the state force structures, mainly with the aim of building up their combat traditions, which were born in the struggle with the external class enemy and domestic "reaction". (In Poland the struggle was carried out by an Army; in Czechoslovakia it was, rather, the National Security Corps.)

While Czechoslovak propaganda extended the discreditation to the Greek-Catholic Church with the aim of its destruction, the Polish effort used it to solve the "Ukrainian nationality problem", which finally took the form of forced resettlement actions. It applied the principle of collective guilt to the Ukrainian minority in Poland, which made it possible, through Operation Vistula, to disperse the remains of the population in the area of western and northwestern Poland for assimilation. Typically, Polish victims of the Banderites were praised while Ukrainian victims were not mentioned. The propaganda of the following years continued to maintain the distorted image of the Ukrainian, or of Ukrainian-Polish hostility, through proven tools (including the press, non-fiction and fiction literature, and cinematography). These measures ultimately strengthened the process of "national self-censorship" and accelerated an assimilation of the minority. In relation to the Ukrainian minority in Czechoslovakia, communist propaganda had no reason to create social tensions, as Ukrainian-Slovak relations in Eastern Slovakia were trouble-free and the significant assimilation of Ukrainians was under the influence of other factors. Therefore, the Banderite issue was presented in some way as exported from Poland. (The origin of the Ukrainian resistance in the USSR was not mentioned on principle: it was not deemed appropriate). As in Poland, in Czechoslovakia too the issue of the UPA was subject to certain conjunctural waves of interest, dependent upon the current political demands or usefulness, but always according to the established and politically accepted template. Black-and-white interpretations, propaganda fictions and twisted facts, and the concealment of some and the disproportionate highlighting of other facts, which also took place in the literary and film works of the real-socialist period, merely jeopardised the pursuit of historical objectivity and created a complicated stereotype in the historical memory. Paraphrasing the Polish historian G. Motyka, we can sum up that we often do not even realise to what extent today's views on the Polish-Ukrainian conflict and on the UPA are the result of long-term communist propaganda. It has penetrated deeply into the collective consciousness, but it is also reflected in the opinions of historians. ${ }^{82}$

In contrast to their similarly working mechanisms of propaganda, however, the official state cultural policies of Poland and Czechoslovakia were very different in regard to the Ukrainian minority. Speaking of communist Poland, the creating of a picture of the "Ukrainian Banderite"

${ }^{82}$ MOTYKA, Grzegorz. O niektorych trudnościach badania konfliktu polsko-ukraińskiego w latach 1943-1947. In: Kultura i Społeczeństwo, 1993. vol. 37, is. 4, p. 166. 
R. Drozd, M. Šmigel': The extinction of the Ukrainian culture of the Polish-Ukrainian-Slovak borderland...

in the country's cultural policy has not taken much space. This was done by propaganda, which used fiction, film, press, and radio. No state museum was set up, except one in Jabłonka (dedicated to K. Świerczewski), and no exhibitions related to the fight against the UPA were exhibited. There were no theatrical performances on this topic. To put it simply, the communist regime used the mechanisms of the so-called mass culture to disrupt the image of the Ukrainians. It would reach as many people as possible in its goals. The partial ministries of culture in socialist Poland did not deal with the Ukrainian question. From 1956, the functioning of the Ukrainian Socio-Cultural Association was not subordinated to the Ministry of Culture but to the Ministry of the Interior (!). The activity of this Ukrainian association was limited to "outside national and socialist inside" by the government. Finally, activities related to the "resurrection" of the Ukrainian culture in the region of south-eastern Poland, initiated by Teodor Gocz (and other Ukrainian activists) in the 1950s and 1960s, and the establishment of a private open-air Museum of the Lemko culture in Zyndranowa, irritated Polish communist authorities. This museum's very existence was contrary to official propaganda. On the one hand, it reminded that the area had previously been inhabited by Lemkos, and that could raise questions among the curious: what had happened to them, and why were they displaced? On the other hand, it pointed out that the "Polish" Ukrainians (including Lemkos) had fought in the Red Army for the liberation of Poland, and that many of them had died in a battle of the Dukla Pass. That is why in 1976 government authorities ordered the demolishment of a memorial built by T. Gocz, and the persecution of its creator.

At that time, Ukrainian culture literally flourished under the communist regime in Czechoslovakia. After the destruction of the Greek-Catholic Church (1950), the demise of the russophile Ukrainian National Council of Priashevshchina (1952), and, paradoxically, during the trials of the "Ukrainian bourgeois nationalists" in Slovakia, government policy focused on the process of the so-called "Ukrainianisation" of the Ruthenians of north-eastern Slovakia. The purposeful Ukrainianisation, enforced and monitored by state and political authorities, began in the early 1950s with the construction of Ukrainian schools. It also included a cultural policy managed through the Cultural Union of Ukrainian Workers, which was established in 1951 in Prešov with the aim of spreading Ukrainian culture. Prešov also housed the Ukrainian National Theatre (from 1946), and there was also Ukrainian radio broadcasting. The Association of Ukrainian Writers of Slovakia was established in the town and many Ukrainian newspapers and magazines were published there (Nove žyt't’a, Družno vpered, Dukl'a, Veselka). In 1956 the Museum of Ukrainian Culture (in Czechoslovakia at that time the only one focusing on a particular nationality) was established in Prešov, and moved to Svidník in 1964. Finally the annual Cultural Festival of Ukrainian Workers began to take place in the town. ${ }^{83}$ In addition to the occurrence of such rich cultural activities of Ukrainians in Slovakia, the issue of the Banderites was practically marginalised; more precisely it was "tactically disappeared in a short time" (it remaining a post-war military affair, or a matter of "Polish" Ukrainians). It was simply not appropriate to commemorate this topic in all segments of the cultural affairs of the "Ukrainian working people". There was no book concerning the UPA written by Ukrainian writers in Slovakia, no exhibitions exhibited, and no plays performed. The image of the "Ukrainian Banderite" had been "swept" into the south-eastern corner of Poland and the theme of the national liberation struggle of the Ukrainians in the USSR had become a "taboo".

\footnotetext{
${ }^{83}$ See: KONEČNÝ, Stanislav. Kultúrne aspekty vývoja rusínskej a ukrajinskej menšiny na Slovensku v povojnovom decéniu. In: Clovek a spoločnost', 2009, vol. 12, is. 1, pp. 43-60.
} 